\title{
Fitoremediasi Logam Berat Kadmium (Cd)
}

\author{
FATMAWATI NUR \\ Jurusan Biologi, Fakultas Sains dan Teknologi, UIN Alauddin Makassar \\ Jl. Sultan Alauddin 36 Samata, Kab. Gowa 92113 \\ email: fatenurkhalik@yahoo.com
}

\begin{abstract}
Phytoremediation consists in treating environmental pollutions through the use of plants and their associated microbes. Phytoremediation can be used for pollutant stabilization, extraction, degradation or volatilization. Cadmium is one of the most toxic trace metallic elements for living organisms and its accumulation in the environment is recognized as a worldwide concern. Plants suitable for efficient pollutant extraction from the soil should combine different characteristics like fast growth, high biomass, high tolerance and high accumulation capacities in harvestable parts. Several studies have shown that plants can accumulate $\mathrm{Cd}$ in the body such as Eichornia crassipes, Brassica napus, Avicenna marina, Lycopersicon esculentum, Wolffia globosa, Phytolacca Americana, Solanum nigrum, Typha domingensis, Sedum plumbizincicola, Thlaspi caerulescens, Helianthus annuus, Lolium perenne, Tagetes erecta, Chara australis, Jatropha curcas, Sedum alfredii, Atriplex halimus, Phragmites cummunis, Nitella opaca, Phragmites australis, Typha angustifolia, Cyperus esculentus, Chara aculeolata, Ricinus communis, Hibiscus cannabinus, Zea mays, Arabidopsis halleri, Arundo donax, and Vetiveria zizanioides.
\end{abstract}

Keywords: Cadmium, Phytoremediation, Plant

\section{PENDAHULUAN}

Seiring dengan kemajuan ilmu pengetahuan dan teknologi yang semakin pesat, manusia telah banyak menciptakan berbagai macam industri yang bertujuan untuk memenuhi kebutuhannya. Selain memberikan dampak yang menguntungkan juga memberikan dampak yang kurang menguntungkan seperti dapat menyebabkan pencemaran lingkungan. Masalah pencemaran lingkungan akhir-akhir ini merupakan masalah yang banyak mendapat perhatian serius.

Salah satu bahan pencemar lingkungan yang banyak menarik perhatian adalah pencemaran oleh logam berat. Pencemaran logam berat merupakan salah satu faktor penyebab timbulnya isu perubahan lingkungan terutama dalam hal pencemaran lingkungan oleh senyawa logam berat beracun. Penyebaran logam berat di tanah, perairan, ataupun udara dapat melalui berbagai hal, seperti pembuangan secara langsung limbah indutri, baik limbah padat maupun limbah cair, dapat pula melalui udara karena banyak industri yang membakar begitu saja limbahnya dan membuang hasil pembakaran ke udara tanpa melalui pengolahan lebih dulu (Palar, 2008).

Jumlah aliran limbah cair yang berasal dari industri sangat bervariasi tergantung dari jenis dan besar kecilnya industri, pengawasan pada proses industri, derajat penggunaan air, dan derajat pengolahan limbah cair yang ada (Darmono, 2008).

Limbah industri dan limbah rumah tangga dapat masuk ke dalam laut melalui sungaisungai dan saluran-saluran pembuangan. Limbah industri dan limbah rumah tangga pada mulanya akan diencerkan dan kekuatan pencemarannya secara perlahan-lahan akan diperlemah sehingga menjadi tidak berbahaya, namum bila buangan tersebut semakin banyak dan melampaui daya dukung lingkungan, maka bahan buangan tersebut secara perlahanlahan akan menumpuk menyebabkan pencemaran yang serius terhadap lingkungan laut misalnya air laut itu sendiri atau sedimen laut (Darmono, 2008).

Logam kadmium akan mengalami proses biotransformasi dan bioakumulasi dalam organisme hidup (tumbuhan, hewan dan manusia). Logam ini masuk ke dalam tubuh 
bersama makanan yang dikonsumsi, tetapi makanan tersebut telah terkontaminasi oleh logam $\mathrm{Cd}$ dan atau persenyawaannya. Dalam tubuh biota perairan jumlah logam yang terakumulasi akan terus mengalami peningkatan. Di samping itu, tingkatan biota dalam sistem rantai makanan turut menentukan jumlah $\mathrm{Cd}$ yang terakumulasi. Di mana pada biota yang lebih tinggi stratanya akan ditemukan akumulasi $\mathrm{Cd}$ yang lebih banyak, sedangkan pada biota top level merupakan tempat akumulasi paling besar. Bila jumlah $\mathrm{Cd}$ yang masuk tersebut melebihi ambang maka biota dari suatu level atau strata tersebut akan mengalami kematian dan bahkan kemusnahan (Palar, 2008).

Pengendalian pencemaran lingkungan merupakan program keamanan pangan nasional yang harus segera dilaksanakan, terlebih lagi akan memasuki era perdagangan bebas. Produk-poduk pertanian dituntut mempunyai standar mutu yang baik serta aman dikonsumsi. Adanya logam berat dalam tanah pertanian dapat menurunkan produktifitas pertanian dan kualitas hasil pertanian selain dapat membahayakan kesehatan manusia melalui konsumsi pangan yang dihasilkan dari tanah yang tercemar logam berat tersebut.

Fitoremediasi. Istilah fitoremediasi berasal dari kata Inggris phytoremediation; kata ini sendiri tersusun atas dua bagian kata, yaitu phyto yang berasal dari kata Yunani phyton (= "tumbuhan") dan remediation yang berasal dari kata Latin remedium (="menyembuhkan", dalam hal ini berarti juga "menyelesaikan masalah dengan cara memperbaiki kesalahan atau kekurangan"). Dengan demikian fitoremediasi dapat didefinisikan sebagai: penggunaan tumbuhan untuk menghilangkan, memindahkan, menstabilkan, atau menghancurkan bahan pencemar baik itu senyawa organik maupun anorganik (Purakayastha et al., 2010).

Fitoremediasi adalah upaya penggunaan tanaman dan bagian-bagiannya untuk dekontaminasi limbah dan masalah-masalah pencemaran lingkungan baik secara ex-situ menggunakan kolam buatan atau reactor maupun in-situ (langsung di lapangan) pada tanah atau daerah yang terkontaminasi limbah
(Morel, et. al., 2006). Teknik fitoremediasi merupakan metode biokonsentrasi bahan berbahaya (polutan) dalam tanah dan air serta merupakan teknologi pemulihan kualitas lingkungan tercemar yang ramah lingkungan dan murah. Teknik fitoremediasi sering dikembangkan untuk pemulihan kualitas lingkungan yang tercemar logam berat seperti $\mathrm{Pb}, \mathrm{Zn}, \mathrm{Au}$ dan pencemar dalam bentuk radioaktif seperti Cs.l. Teknologi ini potensial untuk diaplikasikan, aman untuk digunakan dan dengan dampak negatif relatif kecil, memberikan efek positif yang multiguna terhadap kebijakan pemerintah, komunitas masyarakat dan lingkungan, biaya relatif rendah, mampu mereduksi volume kontaminan, dan memberikan keuntungan langsung bagi kesehatan masyarakat. Keuntungan paling besar dalam penggunaan fitoremediasi adalah biaya operasi lebih murah bila dibandingkan pengolahan konvensional lain seperti insinerasi, pencucian tanah berdasarkan sistem kimia dan energi yang dibutuhkan. Sebagai perbandingan, sistem pencucian logam membutuhkan biaya sekitar US\$ 250/kubik yard sedangkan fitoremediasi hanya membutuhkan US\$ 80/kubik yard. Teknologi fitoremediasi dikembangkan berdasarkan kemampuan beberapa jenis tanaman dalam menyerap beberapa logam renik seperti seng $(\mathrm{Zn})$ dan tembaga $(\mathrm{Cu})$ dalam pertumbuhannya (Terry et al., 2010).

Persyaratan tanaman untuk fitoremediasi, tidak semua tanaman dapat digunakan dikarenakan semua tanaman tidak dapat melakukan metabolisme, volatilisasi dan akumulasi semua polutan dengan mekanisme yang sama. Untuk menentukan tanaman yang dapat digunakan pada penelitian fitoremediasi dipilih tanaman yang mempunyai sifat: cepat tumbuh, mampu mengkonsumsi air dalam jumlah yang banyak pada waktu yang singkat, mampu meremediasi lebih dari satu polutan, dan toleransi yang tinggi terhadap polutan (Morel et. al., 2006).

Fitoremediasi dapat dibagi menjadi fitoekstraksi, rizofiltrasi, fitodegradasi, fitostabilisasi, fitovolatilisasi. Fitoekstraksi mencakup penyerapan kontaminan oleh akar tumbuhan dan translokasi atau akumulasi 
senyawa itu ke bagian tumbuhan seperti akar, daun atau batang. Rizofiltrasi adalah pemanfaatan kemampuan akar tumbuhan untuk menyerap, mengendapkan, dan mengakumulasi logam dari aliran limbah. Fitodegradasi adalah metabolisme kontaminan di dalam jaringan tumbuhan, misalnya oleh enzim dehalogenase dan oksigenase. Fitostabilisasi adalah suatu fenomena diproduksinya senyawa kimia tertentu untuk mengimobilisasi kontaminan di daerah rizosfer. Fitovolatilisasi terjadi ketika tumbuhan menyerap kontaminan dan melepasnya ke udara lewat daun; dapat pula senyawa kontaminan mengalami degradasi sebelum dilepas lewat daun (Tsao, 2003).

Mekanisme kerja fitoremediasi terdiri dari beberapa konsep dasar yaitu: fitoekstraksi, fitovolatilisasi, fitodegradasi, fitostabilisasi, rhizofiltrasi dan interaksi dengan mikroorganisme pendegradasi polutan. Fitoekstraksi merupakan penyerapan polutan oleh tanaman dari air atau tanah dan kemudian diakumulasi/disimpan didalam tanaman (daun atau batang), tanaman seperti itu disebut dengan hiperakumulator. Setelah polutan terakumulasi, tanaman bisa dipanen dan tanaman tersebut tidak boleh dikonsumsi tetapi harus di musnahkan dengan insinerator kemudian dilandfiling. Fitovolatilisasi merupakan proses penyerapan polutan oleh tanaman dan polutan tersebut dirubah menjadi bersifat volatil dan kemudian ditranspirasikan oleh tanaman. Polutan yang di lepaskan oleh tanaman keudara bisa sama seperti bentuk senyawa awal polutan, bisa juga menjadi senyawa yang berbeda dari senyawa awal.

Fitodegradasi adalah proses penyerapan polutan oleh tanaman dan kemudian polutan tersebut mengalami metabolisme didalam tanaman. Metabolisme polutan didalam tanaman melibatkan enzim antara lain nitrodictase, laccase, dehalogenase dan nitrilase. Fitostabilisasi merupakan proses yang dilakukan oleh tanaman untuk mentransformasi polutan didalam tanah menjadi senyawa yang non toksik tanpa menyerap terlebih dahulu polutan tersebut kedalam tubuh tanaman. Hasil transformasi dari polutan tersebut tetap berada didalam tanah. Rhizofiltrasi adalah proses penyerapan polutan oleh tanaman tetapi biasanya konsep dasar ini berlaku apabila medium yang tercemarnya adalah badan perairan (Succuro et. al., 2009).

Fitoakumulasi atau fitoekstraksi merupakan merupakan salah satu proses dalam fitoremediasi yang mencakup 4 hal, yaitu: pengelolaan tanaman pada lokasi tercemar, pemindahan logam melalaui biomassa yang dipanen, dilakukan perlakuan terhadap biomassa yang dipanen berikut pelenyapan biomassa sebagai limbah berbahaya, penghilangan logam dari biomassa yang dipanen. Fitoekstraksi termasuk pendekatan yang paling baik untuk memindahkan kontaminan, terutama dari tanah dan mengisolasinya tanpa merusak struktur tanah dan kesuburan tanah. Proses ini juga dikenal dengan istilah fitoakumulasi. Faktor yang harus diperhatikan agar metode ini sesuai adalah tanaman yang digunakan harus dapat mengekstrak logam dalam konsentrasi yang besar ke dalam akar, kemudian menstranslokasikannya ke tajuk dan memproduksi biomassa tanaman dalam jumlah besar. Pemindahan logam berat dapat didaur ulang kembali dari biomassa tanaman yang telah terkontaminasi. Faktor-faktor tanaman seperti laju pertumbuhan, selektifitas elemen, resisten terhadap penyakit, metode panen juga penting untuk diperhatikan. Namun, pertumbuhan yang lambat, system perakaran yang dangkal, produksi bimassa yang kecil dan pembuangan akhir dapat menjadi pembatas penggunaan spesies hiperakumulator (Purakayastha et. al., 2010).

Fitoakumulasi atau fitoekstraksi adalah penyerapan polutan logam berat $(\mathrm{Ag}, \mathrm{Cd}, \mathrm{Co}$, $\mathrm{Cr}, \mathrm{Cu}, \mathrm{Hg}, \mathrm{Mn}, \mathrm{Ni}, \mathrm{Pb}, \mathrm{Zn}$ ) di dalam tanah oleh akar tumbuhan, dan mengakumulasikan senyawa tersebut ke bagian tumbuhan, seperti akar, batang, atau daun. Kontaminan dihilangkan dari lingkungan dengan cara memanen tanaman dan menjadikannya sebagai limbah. Penekanan teknologinya adalah bahwa daun tanaman mempunyai massa yang jauh lebih kecil dibandingkan dengan tanah dan bahan lain yang selama ini digunakan dalam proses dekontaminasi. Teknik fitoakumulasi 
ini banyak dipakai pada dekontaminasi tanah, sedimen dan sludge (Terry et. al., 2010).

Metode fitoekstraksi sering digunakan untuk dekontaminasi logam $\mathrm{Ag}, \mathrm{Cd}, \mathrm{Co}, \mathrm{Cr}$, $\mathrm{Cu}, \mathrm{Hg}, \mathrm{Mn}, \mathrm{Mo}, \mathrm{Ni}, \mathrm{Pb}, \mathrm{Zn}$. Beberapa unsur radioaktif dilaporkan dapat juga didekontaminasi dengan teknik fitoekstraksi, yaitu Sr-90, Cs-137, Pu-239, U-238, dan U234. Biasanya teknik fitoekstraksi ini diaplikasikan pada tanah atau sedimen yang terkontaminasi dengan metal $(\mathrm{Pb}, \mathrm{Cd}, \mathrm{Zn}, \mathrm{As}$, $\mathrm{Cu}, \mathrm{Cr}, \mathrm{Se}, \mathrm{U})$. Tanaman yang dapat dipakai adalah bunga matahari (Helianthus anuus), indianmustard atau sawi (B. juncea), rapeseed plants (B. napus), barle (Hordeum vulgare, family Poaceae), hops (Humulus lupulus), crucifers (Chinese cabage atau Brassica olerceae atau Bchinensis), serpentine plants Nettles (Urticadioica), dan dandelions (Taraxacum officinale) (Widowati et. al., 2008).

Logam Berat Kadmium. Logam berasal dari kerak bumi yang berupa bahan-bahan murni, organik dan anorganik. Logam mulamula diambil dari pertambangan di bawah tanah (kerak bumi), yang kemudian dicairkan dan dimurnikan dalam pabrik menjadi logamlogam murni. Dalam proses pemurnian logam tersebut yaitu dari pencairan sampai menjadi logam, sebagian darinya terbuang ke dalam lingkungan (Palar, 2008).

Sumber tersebarnya logam dalam lingkungan dan di udara karena proses digunakannya logam tersebut pada suhu yang tinggi. Misalnya, penggunaan batu bara dan minyak bumi untuk pembangkit tenaga listrik, proses industri, peleburan logam, pemurnian logam, pembakaran sampah, dan industri semen. Dalam proses tersebut logam dikeluarkan ke udara di daerah sekitarnya. Logam seperti As, hg, $\mathrm{Cd}$, dan $\mathrm{Pb}$ banyak dipelajari oleh para ilmuan karena keempat logam tesebut sangat berbahaya terhadap kehidupan makhluk hidup. Emisi logam tersebut dalam proses penggunaan suhu tinggi akan merusak siklus biogeokimiawi sistem tata kehidupan manusia dan alam sekitarnya. Untuk mengetahui dan mengukur seberapa jauh kerusakan yang ditimbulkannya perlu diinventarisasikan seberapa besar jumlah konsentrasi emisi dari logam tersebut (Palar, 2008).

Logam berat berbahaya karena umumnya memiliki rapat massa tinggi dan sejumlah konsentrasi kecil dapat bersifat racun dan berbahaya. Logam berat dapat ditemui pada alat-alat rumah tangga (misalnya baterai), rokok, alat-alat elektronik, pipa air, bensin, udara, keramik, serta material lainnya. Konsentrasi logam berat pada barang tersebut kecil dan tidak berbahaya. Namun menjadi berbahaya bila terakumulasi dalam tubuh sehingga mengakibatkan keracunan, bahkan lebih fatal hingga berakibat kematian (Alloway, 2013)

Kadmium (Cd) adalah salah satu logam berat dengan penyebaran yang sangat luas di alam, logam ini bernomor atom 48 berat atom 112,40 dengan titik cair $321^{\circ} \mathrm{C}$ dan titik didih $765^{\circ} \mathrm{C}$. Di alam kadmium bersenyawa dengan belerang (S) ( $\mathrm{ZnS})$. Kadmium merupakan logam lunak (cuctile) berwarna putih perak dan mudah teroksidasi oleh udara bebas dan gas amonia (Palar, 2008).

Logam kadmium sangat banyak digunakan dalam kehidupan sehari-hari manusia. Prinsip dasar atau prinsip utama dalam penggunaan kadmium adalah sebagai bahan "stabilisasi" sebagai bahan pewarna dalam industri plastik dan pada elektroplating. Namun sebagian dari substansi logam kadmium ini juga digunakan untuk solder dan alloy-alloynya digunakan pula pada baterai. Umumnya logam kadmium (Cd) senyawa oksida dari kadmium $(\mathrm{CdO})$, hidrat $\left(\mathrm{CdH}_{2}\right)$, dan Khloridanya paling banyak digunakan dalam industri elektroplating. Selain itu banyak digunakan dalam industri-industri ringan, seperti pada proses pengolahan roti, pengolahan ikan, pengolahan minuman, industri tekstil dan lain-lain, banyak dilibatkan senyawa-senyawa yang dibentuk dengan logam $\mathrm{Cd}$, meskipun penggunaannya hanyalah dengan konsentrasi yang sangat rendah (Cobb, 2008).

Logam kadmium selalu dikeluarkan dalam suatu proses peleburan dan pemurnian logam timah, besi, tembaga maupun emas. Suatu pabrik yang memproduksi logam sulfida selalu menimbulkan pencemaran kadmium di 
alam lingkungannya. Daya penguapan kadmium di daerah industri logam dapat menaikkan pencemaran logam yang bersangkutan, tidak hanya udara bahkan tanah dan tanamanpun dapat tercemar (Darmono, 2008).

Secara sederhana dapat diketahui bahwa kandungan logam kadmium (Cd) akan dapat dijumpai di daerah-daerah penimbunan sampah dan aliran air hujan, selain dalam air buangan. Berdasarkan penelitian yang dilakukan dalam perairan Teluk New York didapatkan bahwa sumber $\mathrm{Cd}$ dalam badan perairan yang dikonstribusi dari air limbah industri sangat sedikit, yaitu $0,6 \%$ dari total kandungan $\mathrm{Cd}$ yang ada. Sedangkan jumlah paling besar dikonstribusi oleh limbah padat yaitu $82 \%$ (Parvau, 2010).

Logam berat kadmium dapat hadir pada daerah atau lingkungan yang bermacammacam dan ini dapat dibagi menjadi 3 golongan yaitu udara, tanah dan air.

Kadmium dan senyawa oksidanya merupakan bentuk senyawa $\mathrm{Cd}$ yang paling banyak ditemukan di udara. Bentuk senyawa kadmium dan oksidanya tersebut merupakan senyawa kadmium yang paling toksik, begitu juga bentuk kloridanya $\left(\mathrm{Cdcl}_{2}\right)$ yang biasanya dibebasakan dari pembakaran sampah (Darmono, 2008).

Kadmium yang terdapat dalam air kebanyakan juga berbentuk ion. Kadmium dalam air laut berbentuk senyawa klorida $\left(\mathrm{CdCl}_{2}\right)$, sedangkan dalam air tawar berbentuk karbonat $\left(\mathrm{CdCo}_{3}\right)$. Pada air payau, yang biasanya terdapat dimuara sungai, kedua senyawa tersebut jumlahnya berimbang.

Logam kadmium diserap oleh hewan air melalui insang dan saluran pencernaan. Karena sifatnya yang toksik, logam ini dapat mematikan. Jika hewan air tersebut tahan terhadap kandungan logam yang tinggi, maka logam kadmium dapat tertimbun di dalam jaringannya, terutama hati dan ginjal. Logam kadmium berikatan dengan protein sehingga disebut metalotionin yang bersifat agak permanen dan mempunyai waktu paruh cukup lama (Darmono, 2008).

Logam berat kadmium melalui persenyawaannya dapat masuk ke lingkungan perairan karena adanya kegiatan manusia, diantaranya:

1) Kegiatan pertambangan logam

Eksploitasi timbunan bijih membongkar permukaan batuan dan sejumlah besar sisa-sisa batuan atau tanah untuk mempercepat kondisi pelapukan. Kegiatan proses pangambilan bijih, peleburan dan penyulingan minyak dapat menyebabkan hamburan dan penimbunan sejumlah besar logam runutan seperti $\mathrm{Cd}, \mathrm{Hg}, \mathrm{Pb}$ dan As ke saluran pembuangan disekitarnya atau pengeluaran langsung ke dalam lingkungan perairan.

2) Limbah rumah tangga yang mengandung persenyawaan kadmium

Jumlah logam berat kadmium yang cukup besar disumbangkan dari cairan limbah rumah tangga oleh sampahsampah metabolik, kondisi pipa-pipa air dan produk-produk konsumen lainnya. Komposisi logam kadmium pada aliran air kota tergantung pada banyak faktor seperti rencana perkotaan, keadaan lahankritis, konstruksi jalan, penggunaan tanah dan ciri-ciri fisik atau klimatologi batang air.

3) Limbah dan buangan industri

Beberapa logam runutan dibuang ke dalam lingkungan perairan melalui cairan limbah industri, demikian juga dengan penimbunan dan pencucian lumpur industri. Pada umumnya terdapat penggunaan untuk tujuan ganda logamlogam dalam sebagian besar industri, walaupun terdapat beberapa contoh pencemaran logam khususnya yang berhubungan dengan indusri tertentu. Emisi gas kadmium dari pembakaran bahan bakar fosil kadmium di udara yang bisa masuk ke dalam air secara alamiah dan daerah aliran sungai.

Di dalam tanah, pada umumnya kandungan logam berat secara alamiah sangat rendah, kecuali tanah tersebut merupakan daerah pertambangan atau tanah tersebut sudah tercemar (Darmono, 2008). Pada suatu daerah yang sudah tercemar $\mathrm{Cd}$, logam tersebut terserap oleh tanaman dalam bentuk ion dari 
dalam tanah melalui akarnya dan didistribusikan dalam bagian tanaman. Jumlah ion $\mathrm{Cd}$ yang diserap oleh tanaman dipengaruhi oleh faktor $\mathrm{pH}$ tanah, kandungan mineral lain, pemupukan. Jika tanaman tersebut dikonsumsi oleh manusia, maka ion kadmium tersebut akan masuk ke dalam tubuh manusia (Darmono, 2008).

Pemasok logam berat dalam tanah pertanian antara lain bahan agrokimia (pupuk dan pestisida), asap kendaraan bermotor, bahan bakar minyak, pupuk organik, buangan limbah rumah tangga, industri, dan pertambangan. Selain itu sumber logam berat dalam tanah berasal dari bahan induk pembentuk tanah itu sendiri, seperti $\mathrm{Cd}$ banyak terdapat pada batuan sedimen schales $(0,22$ ppm berat), Cr pada batuan beku ultrafanik (2, 980 ppm berat), Hg pada bauan sedimen pasir (0,29 ppm berat), $\mathrm{Pb}$ pada batuan granit $(24$ ppm berat (Zoidis, et. al. 2010).

Logam beracun kadmium dapat dibawa ke dalam tubuh oleh seng yang terikat dalam protein (dalam hal ini adalah struktur protein yang mengandung rantai seng). Seng dan kadmium berada dalam satu grup dalam susunan unsur berkala, mempunyai bilangan oksidasi yang sama $(+2)$, jika terionisasi akan membentuk partikel ion yang berukuran hampir sama. Dari banyak kesamaan tersebut, maka kadmium dapat menggantikan rantai seng dalam banyak sistem biologi (organik). Ikatan kadmium dalam zat organik mempunyai kekuatan 10 kali lebih besar dibandingkan dengan seng jika terikat dalam zat organik. Sebagai tambahan, kadmium juga dapat menggantikan magnesium dan kalsium dalam ikatannya dengan struktur zat organik (Palar, 2008).

Fitoremediasi Logam Berat Kadmium. Tumbuhan menyerap elemenn dari lingkungannya. Dalam penyerapan zat tersebut tumbuhan menunjukkan selektivitas namun kadang tumbuhan menyerap elemen yang sesungguhnya tidak diperlukan. Masuknya zat ke dalam jaringan tumbuhan dapat melalui daun (stomata) atau akar. Pada akar, zat masuk ke dalam sel dengan cara difusi baik difusi aktif maupun difusi pasif (Taiz, 2010). Penyerapan aktif dilakukan melalui membran yang tidak permeabel dan memerlukan perantaraan senyawa yang disebut "carrier" (pembawa) yang terdapat dalam membran. Membran sel merupakan perintang bagi ionion yang akan melintasinya sehingga untuk keperluan penyerapan ion oleh sel tumbuhan, peranan pembawa sangat penting. Agar ion dapat masuk ke dalam sel yang konsentrasi ionnya lebih tinggi diperlukan sejumlah energi atau ATP. Pada penyerapan pasif berlangsung pertukaran ion, jadi proses penyerapan zat pada penyerapan pasif merupakan penyerapan yang non metabolik. Ion-ion yang diserap pada permukaan dinding sel dapat bertukar dengan ion-ion dari larutan luarnya. Sebagai contoh kation $\mathrm{K}^{+}$dari larutan luar dapat dipertukarkan dengan ion-ion $\mathrm{H}^{+}$yang diserap pada permukaan membran dengan cara osmotik tidak aktif (Russell et. al., 2012).

Penyerapan $\mathrm{Cd}$ dari tanah oleh tanaman dipengaruhi oleh total pemasukan $\mathrm{Cd}$ dalam tanah, $\mathrm{pH}$ tanah, kandungan $\mathrm{Zn}$, jenis tanaman dan kultivar. Penyerapan $\mathrm{Cd}$ akan tinggi pada $\mathrm{pH}$ rendah dan menurun pada $\mathrm{pH}$ tinggi. Kandungan seng ( $\mathrm{Zn}$ ) yang tinggi dapat mengurangi penyerapan $\mathrm{Cd}$. Jika $\mathrm{Cd}$ telah memasuki rantai makanan, maka pada akhirnya akan terakumulasi pada konsumen tingkat tinggi yaitu hewan dan manusia. Kadmium sangat membahayakan kesehatan karena pengaruh racun akut dari unsur tersebut sangat buruk (Lin et. al.,2012).

Logam kadmium akan mengalami proses biotransformasi dan bioakumulasi dalam organisme hidup (tumbuhan, hewan dan manusia). Logam ini masuk ke dalam tubuh bersama makanan yang dikonsumsi, tetapi makanan tersebut telah terkontaminasi oleh logam $\mathrm{Cd}$ dan atau persenyawaannya. Dalam tubuh biota perairan jumlah logam yang terakumulasi akan terus mengalami peningkatan. Di samping itu, tingkatan biota dalam sistem rantai makanan turut menentukan jumlah $\mathrm{Cd}$ yang terakumulasi. Di mana pada biota yang lebih tinggi stratanya akan ditemukan akumulasi Cd yang lebih banyak, sedangkan pada biota top level merupakan tempat akumulasi paling besar. Bila jumlah $\mathrm{Cd}$ yang masuk tersebut melebihi ambang maka biota dari suatu level atau strata tersebut akan 
mengalami kematian dan bahkan kemusnahan (Nowrouzi, et. al., 2012).

Penelitian tentang akumulasi logam $\mathrm{Cd}$ dalam tubuh tanaman telah dilakukan pada tanaman sawi hijau (Brassica juncea) yang dipasarkan di pasar Terong kota Makassar, yang berasal dari 3 lokasi tanah pertanian yaitu: pada sampel 1 berasal dari desa To'dotoa Kecamatan Palangga sedangkan sampel 2 dan 3 berasal dari desa Bonto Pa'ja Kecamatan Barombong. Tujuan penelitian ini adalah untuk mengetahui kandungan kadmium yang terakumulasi dalam tubuh tanaman sawi hijau (Brassica juncea). Penelitian ini dianalisa secara deskriptif yang dipaparkan dalam bentuk tabel dan gambar. Analisa sampel dilakukan dengan menggunakan metode Spektrofotometer Serapan Atom (SSA). Bahwa kandungan kadmium (Cd) yang terakumulasi paling tinggi adalah pada organ akar yaitu dengankonsentrasi; A1 0.3288 ppm; A2 0.2498 ppm; A3 0.21225 ppm. Kemudian menyusul daun yaitu dengan konsentrasi: $\mathrm{C} 1$ 0.123 ppm; C2 0.12925 ppm; C3 0.1718 ppm. Yang paling rendah yaitu pada batang dengan konsentrasi: B1 0.0253 ppm; B2 0.0540 ppm; B3 0.0635 ppm (Rosdiana, et. al., 2009).

Akumulasi $\mathrm{Cd}$ juga telah diteliti pada tanaman kangkung darat (Ipomoea reptans) di dusun Borong Karamasa desa Toddotoa kecamatan Pallangga kabupaten Gowa. Tujuan penelitian ini yaitu untuk mengetahui kadar konsentrasi logam Kadmium (Cd) yang terakumulasi oleh tanaman kangkung darat (Ipomoea reptans). Metode penelitian yang digunakan adalah deskriptif dengan mengukur kadar kandungan kadmium (Cd) kangkung darat (Ipomoea reptans) pada organ akar, batang dan daun pada pengujian dengan SSA (Spektrofotometer Serapan Atom).

Hasil yang diperoleh menunjukkan bahwa pada sampel 1 organ akar yaitu sebanyak $0.4303 \mathrm{ppm}$, batang sebanyak $0.1513 \mathrm{ppm}$ dan daun sebanyak $0.1667 \mathrm{ppm}$. Pada sampel 2 organ akar yaitu sebanyak $0.1608 \mathrm{ppm}$, batang sebanyak 0.1860 ppm dan daun sebanyak $0.1670 \mathrm{ppm}$. Pada sampel 3 organ akar yaitu sebanyak 0.2239 ppm, batang sebanyak 0.1375 ppm dan daun sebanyak 0.1587 ppm (Suhaeni, et. al., 2009).
Berdasarkan hasil penelitian, beberapa tanaman teridentifikasi dapat dimanfaatkan pada proses fitoremediasi karena kemampuannya mengakumulasi logam berat Cd diantaranya adalah: Eichornia crassipes (Módenes, et. al., 2011), Brassica napus (Nakamura, et. al., 2013), Avicenna marina (Nowrouzi, et. al., 2012), Lycopersicon esculentum ( Sbartai, et. al., 2012), Wolffia globosa (Xie, et. al., 2013), Phytolacca americana (Gao, et al., 2013), Solanum nigrum (Wei, et al., 2013), Typha domingensis (Bonanno, 2013), Sedum plumbizincicola ( $\mathrm{Wu}$, et al., 2012), Thlaspi caerulescens (Koopmans, et al., 2008), Helianthus annuus (Niu, et al., 2013), Lolium perenne (Gunawardana, et al., 2011), Tagetes erecta (Sinhal, et al., 2010), Chara australis (Clabeaux, et al., 2011), Jatropha curcas (Jamil, et al., 2009), Sedum alfredii (Li, et al., 2013), Atriplex halimus (Manousaki \& Kalogerakis, 2009), Phragmites cummunis (Chandra \& Yadav, 2011), Nitella opaca (Sooksawat, et al., 2013), Phragmites australis (Wang \& Jia, 2009), Typha angustifolia (Muhammad, et al., 2009), Cyperus esculentus (Chandra \& Yadav, 2011), Chara aculeolata ((Sooksawat, et al., 2013), Ricinus communis (Ruiz, et al., 2013), Hibiscus cannabinus (Arbaoui, et al., 2013), Zea mays (Hechmi, et al., 2013), Arabidopsis halleri (Claire-Lise \& Nathalie, 2012), Arundo donax (Barbafieri, et al., 2011), dan Vetiveria zizanioides (Danh, et al., 2009).

\section{KESIMPULAN}

Fitoremediasi terdiri dalam mengobati pencemaran lingkungan melalui penggunaan tanaman dan mikroba yang terkait. Fitoremediasi dapat digunakan untuk stabilisasi polutan, ekstraksi, degradasi atau penguapan. Kadmium adalah salah satu elemen logam jejak yang paling toksik bagi organisme hidup dan akumulasi dalam lingkungan diakui sebagai keprihatinan di seluruh dunia. Tanaman yang cocok untuk ekstraksi polutan yang efisien dari tanah harus menggabungkan karakteristik yang berbeda seperti pertumbuhan cepat, biomassa tinggi toleransi yang tinggi dan kapasitas tinggi 
dalam akumulasi bagian dipanen . Beberapa studi telah menunjukkan bahwa tanaman dapat mengakumulasi $\mathrm{Cd}$ dalam tubuh Eichornia crassipes, Brassica napus, Avicenna marina, Lycopersicon esculentum, Wolffia globosa, Phytolacca Americana, Solanum nigrum, Typha domingensis, sedum plumbizincicola, Thlaspi caerulescens, Helianthus annuus, Lolium perenne, Tagetes erecta, Chara australis, Jatropha curcas, sedum alfredii, Atriplex halimus, Phragmites cummunis, Nitella opaca, Phragmites australis, Typha angustifolia, Cyperus esculentus, Chara aculeolata, Ricinus communis, Hibiscus cannabinus, Zea mays, Arabidopsis halleri, Arundo donax, dan Vetiveria zizanioides .

\section{DAFTAR PUSTAKA}

Alloway BJ. 2013. Heavy Metals in Soils: Trace Metals and Metalloids in Soils and their Bioavailability. Environmental Pollution. vol 22. 3rd Edition. Netherlands: Springer.

Arbaoui S, Evlard A, Mhamdi MW, Campanella B, Paul R, Bettaieb T. 2013. Potential of Kenaf (Hibiscus cannabinus L.) and Corn (Zea mays L.) For Phytoremediation Of Dredging Sludge Contaminated By Trace Metals. Biodegradation. vol 24 (4): 563-567.

Barbafieri M, Dadea C, Tassi E, Bretzel F, Fanfani L. 2011. Uptake of heavy metals by native species growing in a mining area in Sardinia, Italy: Discovering Native Flora for Phytoremediation. Int $J$ Phytoremediation. vol 13(10):985-97.

Bonanno G. 2013. Comparative Performance of Trace Element Bioaccumulation and Biomonitoring in The Plant Species Typha domingensis, Phragmites australis And Arundo donax. Ecotoxicol Environ Saf. vol 97:124-30.

Chandra R and Yadav S. 2011. Phytoremediation of $\mathrm{Cd}, \mathrm{Cr}, \mathrm{Cu}, \mathrm{Mn}, \mathrm{Fe}$, $\mathrm{Ni}, \mathrm{Pb}$ and $\mathrm{Zn}$ From Aqueous Solution Using Phragmites cummunis, Typha angustifolia and Cyperus esculentus. Int $J$ Phytoremediation. vol 13(6):580-91.

Clabeaux BL, Navarro DA, Aga DS, and Bisson MA. 2011. Cd Tolerance and
Accumulation in The Aquatic Macrophyte, Chara Australis: Potential Use For Charophytes in Phytoremediation. Environ Sci Technol. vol 45(12):5332-8.

Claire LM, and Nathalie V. 2012. The use of the model species Arabidopsis halleri towards phytoextraction of cadmium polluted soils. N Biotechnol. Vol 15;30(1):9-14.

Cobb AB. 2008. Cadmium. New York: Marshall Cavendish Benchmark.

Danh LT, Truong P, Mammucari R, Tran T, Foster N. 2009. Vetiver grass, Vetiveria zizanioides: a choice plant for phytoremediation of heavy metals and organic wastes. Int $J$ Phytoremediation. vol 11(8):664-91.

Darmono. 2008. Lingkungan Hidup dan Pencemaran: Hubungannya Dengan Toksikologi Senyawa Logam. Jakarta: UI Press.

Gao L, Peng K, Xia Y, Wang G, Niu L, Lian C, and Shen Z. 2013. Cadmium and Manganese Accumulation in Phytolacca Americana L. and The Roles Of NonProtein Thiols and Organic Acids. Int $J$ Phytoremediation. vol 15(4):307-19.

Gunawardana B, Singhal N, Johnson A. 2011. Effects of Amendments On Copper, Cadmium, and Lead Phytoextraction by Lolium Perenne from Multiple-Metal Contaminated Solution. Int $J$ Phytoremediation. vol 13(3):215-32.

Hechmi N, Ben Aissa N, Abdennaceur H, Jedidi N. 2013. Phytoremediation Potential of Maize (Zea mays L.) In CoContaminated Soils with Pentachlorophenol and Cadmium. Int $J$ Phytoremediation. vol 15(7):703-13.

Jamil S, Abhilash PC, Singh N, Sharma PN. Jatropha curcas: A Potential Crop for Phytoremediation of Coal Fly Ash. J Hazard Mater. vol 172(1):269-75.

Koopmans GF, Römkens PF, Fokkema MJ, Song J, Luo YM, Japenga J, Zhao FJ. 2008. Feasibility of Phytoextraction To Remediate Cadmium and Zinc Contaminated Soils. Environ Pollut. vol 156(3):905-14. 
Lin YF and Aarts MG. 2012. The Molecular Mechanism of Zinc and Cadmium Stress Response in Plants. Cell Mol Life Sci. vol 69(19):3187-206

Li T, Liang C, Han X, and Yang X. 2013. Mobilization of Cadmium by Dissolved Organic Matter in The Rhizosphere of Hyperaccumulator Sedum alfredii. Chemosphere. vol 91(7):970-6.

Manousaki E and Kalogerakis N. 2009. Phytoextraction of $\mathrm{Pb}$ and $\mathrm{Cd}$ by The Mediterranean Saltbush (Atriplex halimus L.): Metal Uptake In Relation To Salinity. Environ Sci Pollut Res Int. vol 16(7):84454.

Módenes AN, Espinoza-Quiñones FR, Borba CE, Trigueros DE, Lavarda FL, Abugderah MM, and Kroumov AD. 2011. Adsorption of $\mathrm{Zn}$ (II) and $\mathrm{Cd}(\mathrm{II})$ Ions in Batch System by Using The Eichhornia Crassipes. Water Sci Technol. vol 64(9):1857-63.

Morel JL, Echevarria G, and Goncharova N. 2006. Phytoremediation of MetalContaminated Soils. Netherland: Springer.

Muhammad D, Chen F, Zhao J, Zhang G, and Wu F. 2009. Comparison of EDTA and Citric Acid-Enhanced Phytoextraction of Heavy Metals in Artificially Metal Contaminated Soil by Typha angustifolia. Int J Phytoremediation. vol 11(6):558-74,

Nakamura S, Suzui N, Nagasaka T, Komatsu F, Ishioka NS, Ito-Tanabata S, Kawachi $\mathrm{N}$, Rai H, Hattori $\mathrm{H}$, Chino $\mathrm{M}$, and Fujimaki S. 2013. Application of Glutathione to Roots Selectively Inhibits Cadmium Transport from Roots to Shoots in Oilseed Rape. $J$ Exp Bot. vol 64(4):1073-81.

Niu Z, Li X, Sun L, and Sun T. 2013. Dynamics of Three Organic Acids (Malic, Acetic and Succinic Acid) in Sunflower Exposed to Cadmium and Lead. Int $\mathrm{J}$ Phytoremediation. vol 15(7):690-702.

Nowrouzi M, Pourkhabbaz A, and Rezaei M. 2012. Bioaccumulation and Distribution of Metals in Sediments and Avicenna Marina Tissues in The Hara Biosphere
Reserve, Iran. Bull Environ Contam Toxicol. vol 89(4):799-804

Palar H. 2008. Pencemaran dan Toksikologi Logam Berat. Bandung: Rineka Cipta.

Parvau RG. 2010. Cadmium in The Environment. New York: Nova Science Pub Inc.

Purakayastha TJ and Chhonkar PK. 2010. Phytoremediation of Heavy Metal Contaminated Soils. Berlin Heidelberg: Springer.

Rosdiana, Muhiddin, Nur F. 2009. Kandungan Logam Berat Kadmium pada Tanaman Sawi Hijau (Brassica juncea) yang Dipasarkan di Pasar Terong Kota Makassar. [Skripsi] Jurusan Biologi Fakultas Sains dan Teknologi UIN Alauddin Makassar. Makassar.

Ruiz OA, Carrillo-González R, GonzálezChávez MC, and Soto HRM. 2013. Potential of Castor Bean (Ricinus communis L.) for Phytoremediation of Mine Tailings and Oil Production. $J$ Environ Manage. vol 15(114):316-23.

Russell J, and Cohn R. 2012. Plant Physiology. Norderstedt: VSD Publishing.

Sbartai H, Djebar MR, Sbartai I, and Berrabbah H. 2012. Bioaccumulation of Cadmium and Zinc in Tomato (Lycopersicon esculentum L.) C R Biol. vol 335(9):585-93.

Sinhal VK, Srivastava A, and Singh VP. 2010. EDTA and Citric Acid Mediated Phytoextraction of $\mathrm{Zn}, \mathrm{Cu}, \mathrm{Pb}$ and $\mathrm{Cd}$ Through Marigold (Tagetes erecta). J Environ Biol. vol 31(3):255-9.

Sooksawat N, Meetam M, Kruatrachue M, Pokethitiyook P, and Nathalang K. 2013. Phytoremediation Potential of Charophytes: Bioaccumulation and Toxicity Studies of Cadmium, Lead and Zinc. $J$ Environ Sci (China). vol 25(3):596-604.

Suhaeni, Muhiddin, and Nur F. 2009. Bioakumulasi Logam Berat Kadmium (Cd) pada Tanaman Kangkung Darat (Ipomoea reptans) di Dusun Borong Karamasa Desa Toddotoa Kecamatan Pallangga Kab Gowa. [Skripsi]. 
Makassar: Jurusan Biologi Fakultas Sains dan Teknologi UIN Alauddin Makassar.

Taiz L. 2010. Plant Physiology. $5^{\text {th }}$ edition. Sunderland: Sinauer Associates, Inc.

Terry N and Banuelos GS. 2010. Phytoremediation of Contaminated Soil and Water. Oxford: Taylor \& Francis.

Tsao DT. 2003. Phytoremediation. Advance in Biochemical Engineering Biotechnology. Volume 78. Berlin Heidelberg: Springer.

Wang H and Jia Y. 2009. Bioaccumulation of Heavy Metals by Phragmites Australis Cultivated in Synthesized Substrates. $J$ Environ Sci (China). vol 21(10):1409-14.

Wei S, Clark G, Doronila AI, Jin J, and Monsant AC. 2013. Cd Hyperaccumulative Characteristics of Australia Ecotype Solanum nigrum L. and Its Implication in Screening
Hyperaccumulator. Int $J$ Phytoremediation. vol 15(3):199-205.

Wu L, Li Z, Akahane I, Liu L, Han C, Makino T, Luo Y, and Christie P. 2012. Effects of Organic Amendments on $\mathrm{Cd}, \mathrm{Zn}$ and $\mathrm{Cu}$ Bioavailability in Soil with Repeated Phytoremediation by Sedum Plumbizincicola. Int $J$ Phytoremediation. vol 14(10):1024-38.

Xie WY, Huang Q, Li G, Rensing C, and Zhu YG. 2013. Cadmium Accumulation in The Rootless Macrophyte Wolffia Globosa and Its Potential for Phytoremediation. Int J Phytoremediation. vol 15 (4):385-97.

Zoidis E, Fegeros K, Zervas G, Surai PF, Pappas AC. 2010. Cadmium Toxicity and The Antioxidant System. New York: Nova Science Pub Inc. 